\title{
Characterization of mandarin citrus germplasm from Southern Brazil by morphological and molecular analyses ${ }^{(1)}$
}

\author{
Patrícia Koehler-Santos ${ }^{(2)}$, Ana Lúcia Cunha Dornelles ${ }^{(3)}$ and Loreta Brandão de Freitas ${ }^{(2)}$
}

\begin{abstract}
The objective of this work was to characterize mandarin (Citrus spp.) germplasm from Southern Brazil by morphological and molecular analyses. Thirty seven cultivars from 34 distinct mandarin varieties were evaluated by morphological and agronomic traits of leaves, flowers and fruits, and by microsatellite markers. The morphological and agronomic characteristics suggested that almost all varieties can be produced for commercial use, and some, as the Satsuma variety, are recommended for breeding programs. Pooled DNA samples from 1-5 plants belonging to each cultivar were tested. Eight of the nine primers detected polymorphisms. Specific markers were found for some accessions. The dendrogram constructed with the morphological results divided the 37 cultivars into four groups, while that obtained with the microsatellites clustered 35 of the 37 cultivars into three groups only. Generally, intervarietal differences are not high, and this lack of agreement in the two multifactorial analyses indicates that diverse evolutionary factors are acting at these two levels of investigation.
\end{abstract}

Index terms: citrus, genetic variation, microsatellites, breeding methods.

\section{Caracterização do germoplasma de tangerineiras do Sul do Brasil mediante análises morfológicas e moleculares}

\begin{abstract}
Resumo - O objetivo deste trabalho foi caracterizar o germoplasma de tangerineiras (Citrus spp.) por meio de análises morfológicas e moleculares. Trinta e sete cultivares, pertencentes a 34 variedades distintas de tangerineiras, foram avaliadas pelas características morfológicas e agronômicas de folhas, flores e frutos, bem como por análises de microssatélites. As características morfológicas e agronômicas sugerem que praticamente todas as variedades podem ser usadas comercialmente e algumas delas, como a variedade Satsuma, são recomendadas para uso em cruzamentos dirigidos. O DNA foi obtido de amostras extraídas de uma a cinco plantas de cada cultivar. Oito de nove primers detectaram polimorfismos. Foram encontrados marcadores específicos para alguns acessos. O dendrograma construído com os resultados morfológicos dividiu as 37 cultivares em quatro grupos, enquanto o obtido com os microssatélites agrupou 35 das 37 cultivares em três grupos. As diferenças intervarietais não são grandes, e esta falta de concordância nas duas análises multivariadas indica que fatores evolutivos diversos estão agindo nesses dois níveis de investigação.
\end{abstract}

Termos para indexação: citros, variação genética, microsatélites, método de melhoramento.

\section{Introduction}

Mandarins (Citrus spp.) are the second most important group of citrus plants in the world, with

\footnotetext{
(1) Accepted for publication on March 13, 2003.

(2) Universidade Federal do Rio Grande do Sul (UFRGS), Instituto de Biociências, Dep. de Genética, Caixa Postal 15053, CEP 91501-970 Porto Alegre, RS. E-mail: patriciakoehler@hotmail.com, loreta.freitas@ufrgs.br

(3) UFRGS, Fac. de Agronomia, Dep. de Horticultura e Silvicultura, Caixa Postal 776, CEP 90001-970 Porto Alegre, RS. E-mail: al_cunha@terra.com.br
}

the highest climatic adaptation among the cultivated citrus. Brazil is considered the fourth largest mandarin producer in the world, with an annual production estimated in 760,000 tons, and a planted area of 31,000 ha (FAO, 2000). However, despite the high diversity presented by this group of citrus, only a small number of cultivars are used commercially.

The State of Rio Grande do Sul presents favorable climatic conditions for citriculture. These conditions, associated with a small properties' culture system (an average of two hectares) supply its market, but the low production, estimated in 12,000 ha of planted 
area, do not attend all needs satisfactorily. Moreover, the fact that the culture and its commercialization are restricted to few varieties, offered in a small period during the year, causes the needs to import the product (Bastianel, 1999). For these reasons, a Brazilian mandarin breeding program is essential to investigate the available genetic resources (species and varieties), and to supply the market demands.

Several authors investigated and characterized morphologically different selections of citrus plants, in order to increase the number of genotypes with potential to be used in breeding programs or to be released as new varieties. Characters related to plants, flowers, fruits and leaves were used by several authors (Domingues et al., 1999) to describe and characterize distinct mandarin varieties and its hybrids. Sartori et al. (1997) determined the maturation period of the different mandarin genotypes used in the present work.

The use of molecular markers has been a valuable and precise instrument to assist the genetic breeding of citrus species. Techniques like RFLP(Restriction Fragment Length Polymorphism) and RAPD (Random Amplified Polymorphic DNA) were used in germplasm characterization, studies of genetic diversity, phylogenetic analyses, and systematics (Coletta Filho et al., 1998, 2000; Fang et al., 1998; Federici et al., 1998; Nicolosi et al., 2000).

Microsatellites are sequences with one to four nucleotides, moderately repetitive in tandem, that are abundant in the euchromatin of vertebrates, insects and plants. They are considered ideal markers for genetic and physical genome mapping, identification and discrimination of genotypes, studies of population genetics, inbred line characterization, forensic studies, and medical genetics. In citrus, this marker has been used in studies of phylogenetic analysis and linkage (Kijas et al., 1995, 1997; Thomas et al., 1998).

The objective of this work was to characterize mandarin citrus germplasm by morphological and molecular analyses.

\section{Material and Methods}

Evaluated plants belong to the varieties collection of the Estação Experimental Agronômica of the Universidade
Federal do Rio Grande do Sul (EEA/UFRGS), in Eldorado do Sul, RS, Brazil, at latitude $30^{\circ} 29^{\prime} \mathrm{S}$ and longitude $51^{\circ} 6^{\prime} \mathrm{W}$. They were grown in an Yellow Red Podzolic Soil, and were grafted mainly in Rangpur lime. Plants were cultivated with intervals of five meters between plants in the rows, and of eight meters between rows. Thirty-seven accessions of 34 distinct varieties had been analyzed, totalizing 140 plants (Table 1 ).

Thirty mature fruits of each plant were evaluated, collected biweekly randomly and according to their maturation time (Sartori et al., 1997). They were characterized for external and internal, qualitative and quantitative traits. Fifty leaves of each plant were also collected and characterized. Morphologic features - the qualitatives as leaf form, flowers arrangement, flower or inflorescence position, fruit shape, epicarp color, epicarp surface, adherence of epicarp to mesocarp and pulp color and the quantitatives as leaf length, leaf width, petiole length, blooming time (beginning and end), fruit diameter (horizontal and vertical), epicarp thickness, number of segments and seeds per fruit - were chosen on the basis of the Morphologic Descriptors for Citrus of the International Board for Plant Genetic Resources (1988), aiming agronomic interests (Tables 2 and 3).

Five to six healthy young leaves of each plant were randomly collected and stored in silica gel for DNA extraction. The DNA of each variety was pooled to characterize their gene pool (number of plants of each variety indicated in Table 1), since the interplant differences were minimal.

Extraction of the genomic DNA was carried out as in Doyle \& Doyle (1987). The amplification reactions were accomplished in volumes of $25 \mu \mathrm{L}$ with $50 \mathrm{ng}$ of DNA, 2.5 units of Taq DNA polymerase, 4.0 pmol of each primer (F/R), buffer 10x [75 mM Tris- $\mathrm{HCl}, 50 \mathrm{mM} \mathrm{KCl,} 20 \mathrm{mM}$ $\left.\left(\mathrm{NH}_{4}\right)_{2} \mathrm{SO}_{4}\right], 2.0 \mathrm{mM}$ dNTPs and $2.5 \mathrm{mM}$ of $\mathrm{MgCl}_{2}$. The amplification conditions were established for 32-37 cycles of $1 \mathrm{~min}$ in $94^{\circ} \mathrm{C}, 30 \mathrm{sec}$ to $1 \mathrm{~min}$ and $30 \mathrm{sec}$ in $51^{\circ} \mathrm{C}-56^{\circ} \mathrm{C}$, 1 to $2 \mathrm{~min}$ in $72^{\circ} \mathrm{C}$, with an initial denaturation of $5 \mathrm{~min}$ in $94^{\circ} \mathrm{C}$ and a final extension of $4 \mathrm{~min}$ in $72^{\circ} \mathrm{C}$. The list of primers used, supplied by the Centro de Citricultura "Sylvio Moreira" (CCSM)/IAC/SP, and their annealing temperatures, are presented in Table 4 . The amplification products were visualized in an ultraviolet transilluminator, after horizontal electrophoresis in 3\% agarose gel, using the TBE $1 \mathrm{x}$ buffer, the gel being stained with ethidium bromide.

The morphological and molecular results were analyzed using the Numerical Taxonomy and Multivariate Analysis System (NTSYS) - version 1.7 (Rohlf, 1992). Dendrograms were generated by the Unweighted Pair 
Group Method with Arithmetic Average (UPGMA) algorithm (Sneath \& Sokal, 1973) using the Manhattan distance and following the procedures detailed in the NTSYS program.

\section{Results and Discussion}

Leaf length and width were classified as medium in approximately $70 \%$, and petiole length as small in

Table 1. Mandarin varieties from the varieties collection of the Estação Experimental Agronômica of the Universidade Federal do Rio Grande do Sul (EEA/UFRGS) considered in the morphologic and molecular analyses and number of plants analyzed.

\begin{tabular}{|c|c|c|c|}
\hline Taxonomic classification $^{(1)}$ & Varieties & $\begin{array}{c}\text { Plants } \\
\text { analyzed }\end{array}$ & $\begin{array}{c}\text { Numbers of rows in } \\
\text { which each variety } \\
\text { was cultivated }\end{array}$ \\
\hline \multirow[t]{3}{*}{ Citrus spp. } & 15 de Março & 3 & 2 \\
\hline & De Marco & 4 & 2 \\
\hline & Lady & 5 & 5 \\
\hline C. clementina Hort. ex Tan. & Clementina & 5 & 7 \\
\hline \multicolumn{4}{|l|}{ C. paradisi Macf.) } \\
\hline C. clementina Hort. ex Tan. x C. tangerina Hort. ex Tan. & Michal & 5 & 2 \\
\hline \multirow[t]{4}{*}{ C. deliciosa Tenore } & Caí & 3 & 22 \\
\hline & Giant of Sicily & 5 & 5 \\
\hline & Montenegrina & 3 & 4 \\
\hline & Montenegrina cedo & 2 & 2 \\
\hline \multirow[t]{2}{*}{ C. nobilis Loureiro } & King & 4 & 7 \\
\hline & Monstruosa & 3 & 21 \\
\hline C. nobilis Loureiro х C. unshiu Marcovitch & Kará & 4 & 6 \\
\hline C. paratangerina Hort. ex Tan. & Emperor & 4 & 5 \\
\hline C. reshni Hort. ex Tan. & Cleópatra & 3 & 10 \\
\hline \multirow[t]{10}{*}{ C. reticulata Blanco } & Cravo $1^{(2)}$ & 4 & 5 \\
\hline & Cravo $2^{(2)}$ & 3 & 19 \\
\hline & Facket & 5 & 6 \\
\hline & Malvasia & 3 & 6 \\
\hline & Murcott $1^{(2)}$ & 5 & 4 \\
\hline & Murcott $2^{(2)}$ & 1 & 18 \\
\hline & Oneco & 5 & 7 \\
\hline & Ortanique & 5 & 7 \\
\hline & Ponkan & 5 & 22 \\
\hline & Ponkan tardia & 5 & 3 \\
\hline \multirow{4}{*}{$\begin{array}{l}\text { C. paradisi Macf.) } \\
\text { (C) }\end{array}$} & Lee $1^{(2)}$ & 4 & 6 \\
\hline & Lee $2^{(2)}$ & 4 & 22 \\
\hline & Osceola & 1 & 22 \\
\hline & Robinson & 1 & 5 \\
\hline C. reticulata Blanco x C. sinensis (L.) Osb. & Ellendale & 4 & 4 \\
\hline $\begin{array}{l}\text { C. sinensis (L.) Osb. } \mathrm{x} \text { (C. nobilis Loureiro } \mathrm{x} \\
\text { C. deliciosa Tenore) }\end{array}$ & Niva & 3 & 3 \\
\hline $\begin{array}{l}\text { C. deliciosa Tenore) } \\
\text { C. sunki Hort. ex Tan. }\end{array}$ & Sunki & 2 & 20 \\
\hline C. tangerina Hort. ex Tan. & Dancy & 4 & 2 \\
\hline C. tankan Hayata & Tankan & 5 & 7 \\
\hline \multirow[t]{2}{*}{ C. unshiu Marc. } & Montevideo & 4 & 3 \\
\hline & Satsuma & 4 & 3 \\
\hline C. unshiu Marc. x C. sinensis (L.) Osb. & Hada & 4 & 4 \\
\hline
\end{tabular}

(1)According to Tanaka $(1961,1977) .{ }^{(2)}$ Varieties 'Murcott', 'Cravo' and 'Lee' have two accessions in the EEA/UFRGS varieties collection, which were obtained from different places and have different ages; therefore, the accessions have been treated as different varieties. 
approximately $54 \%$ of the genotypes (Table 3 ). All cultivars presented a brevipetiolate form, and their plants possessed axillary and terminal position of flowers and inflorescences. Fifty-seven percent of the cultivars initiated blooming in the first half of September and $38 \%$ in the second half of August. Blooming ended, in $89 \%$ of the cultivars, in the second half of October, totalizing six weeks as the period of blooming in $57 \%$ of the cultivars.

Most of the cultivars $(73 \%)$ presented an oblate fruit shape (Table 3). Fruit size varied from medium to large in most of them. The most frequent epicarp coloration was orange (73\%); epicarp surface in $70 \%$ of the cultivars was smooth; $62 \%$ of the cultivars

Table 2. Classification of mandarin varieties from the varieties collection of the Estação Experimental Agronômica of the Universidade Federal do Rio Grande do Sul (EEA/UFRGS) considering leaf quantitative characters (mean \pm standard deviation), according to International Board for Plant Genetic Resources (1988) and blooming characteristics.

\begin{tabular}{|c|c|c|c|c|}
\hline Variety & Length $^{(1)}$ & Width $^{(1)}$ & Petiole length $^{(1)}$ & Blooming $^{(2)}$ \\
\hline 15 de Março & $7.63 \pm 0.70(\mathrm{M})$ & $3.36 \pm 0.40(\mathrm{M})$ & $0.80 \pm 0.17(\mathrm{~S})$ & $2 / 4$ \\
\hline Caí & $6.04 \pm 0.79(\mathrm{~S})$ & $2.31 \pm 0.32(\mathrm{~S})$ & $0.86 \pm 0.12(\mathrm{~S})$ & $2 / 4$ \\
\hline Clementina & $8.00 \pm 1.40(\mathrm{M})$ & $3.02 \pm 0.53(\mathrm{M})$ & $0.88 \pm 0.21(\mathrm{~S})$ & $1 / 4$ \\
\hline Cleópatra & $8.18 \pm 1.36(\mathrm{M})$ & $3.27 \pm 0.48(\mathrm{M})$ & $0.75 \pm 0.23(\mathrm{~S})$ & $2 / 4$ \\
\hline Cravo 1 & $7.31 \pm 1.10(\mathrm{M})$ & $3.24 \pm 0.55(\mathrm{M})$ & $0.79 \pm 0.17(\mathrm{~S})$ & $2 / 4$ \\
\hline Cravo 2 & $8.19 \pm 1.40(\mathrm{M})$ & $3.68 \pm 0.74(\mathrm{M})$ & $0.93 \pm 0.21(\mathrm{~S})$ & $2 / 4$ \\
\hline Dancy & $6.93 \pm 1.05(\mathrm{~S})$ & $3.57 \pm 0.72(\mathrm{M})$ & $1.06 \pm 0.23(\mathrm{M})$ & $2 / 4$ \\
\hline De Março & $8.04 \pm 0.93(\mathrm{M})$ & $3.46 \pm 0.63(\mathrm{M})$ & $0.73 \pm 0.17(S)$ & $2 / 4$ \\
\hline Ellendale & $8.75 \pm 1.56(\mathrm{M})$ & $3.38 \pm 0.55(\mathrm{M})$ & $1.50 \pm 0.37(\mathrm{M})$ & $2 / 4$ \\
\hline Emperor & $6.43 \pm 1.48(\mathrm{~S})$ & $2.20 \pm 0.53(\mathrm{~S})$ & $0.70 \pm 0.16(S)$ & $2 / 4$ \\
\hline Facket & $7.92 \pm 1.42(\mathrm{M})$ & $3.39 \pm 1.98(\mathrm{M})$ & $0.90 \pm 0.21(\mathrm{~S})$ & $1 / 3$ \\
\hline Fairchild & $9.17 \pm 1.43(\mathrm{~L})$ & $3.19 \pm 0.44(\mathrm{M})$ & $1.38 \pm 0.25(\mathrm{M})$ & $3 / 4$ \\
\hline Giant of Sicily & $6.93 \pm 0.98(S)$ & $2.40 \pm 0.42(\mathrm{~S})$ & $0.78 \pm 0.15(\mathrm{~S})$ & $2 / 4$ \\
\hline Hada & $8.27 \pm 1.44(\mathrm{M})$ & $3.88 \pm 0.60(\mathrm{M})$ & $1.20 \pm 0.22(\mathrm{M})$ & $2 / 4$ \\
\hline Kará & $9.52 \pm 1.61(\mathrm{~L})$ & $4.10 \pm 0.80$ (L) & $1.95 \pm 0.38$ (L) & $1 / 4$ \\
\hline King & $7.35 \pm 1.41(\mathrm{M})$ & $3.71 \pm 0.90(\mathrm{M})$ & $1.01 \pm 0.23(\mathrm{M})$ & $1 / 3$ \\
\hline Lady & $8.19 \pm 1.38(\mathrm{M})$ & $3.16 \pm 0.55(\mathrm{M})$ & $0.80 \pm 0.21(\mathrm{~S})$ & $2 / 4$ \\
\hline Lee 1 & $8.46 \pm 1.30(\mathrm{M})$ & $3.33 \pm 0.53(\mathrm{M})$ & $0.94 \pm 0.30(\mathrm{~S})$ & $2 / 4$ \\
\hline Lee 2 & $7.74 \pm 1.16(\mathrm{M})$ & $3.55 \pm 0.64(\mathrm{M})$ & $1.08 \pm 0.25(\mathrm{M})$ & $3 / 4$ \\
\hline Malvasia & $6.60 \pm 1.71(\mathrm{~S})$ & $2.95 \pm 0.91(\mathrm{~S})$ & $1.00 \pm 0.22(\mathrm{~S})$ & $1 / 4$ \\
\hline Michal & $10.0 \pm 1.45(\mathrm{~L})$ & $4.50 \pm 0.59$ (L) & $1.29 \pm 0.25(\mathrm{M})$ & $2 / 4$ \\
\hline Monstruosa & $7.16 \pm 1.36(\mathrm{M})$ & $3.15 \pm 0.72(\mathrm{M})$ & $0.68 \pm 0.18(S)$ & $2 / 4$ \\
\hline Montenegrina & $7.07 \pm 0.83(\mathrm{M})$ & $2.31 \pm 0.33(\mathrm{~S})$ & $0.85 \pm 0.15(\mathrm{~S})$ & $1 / 4$ \\
\hline Montenegrina cedo & $5.56 \pm 0.83(S)$ & $2.34 \pm 0.39(\mathrm{~S})$ & $1.17 \pm 3.82(\mathrm{M})$ & $2 / 4$ \\
\hline Montevideo & $8.74 \pm 1.49(\mathrm{M})$ & $4.59 \pm 0.85(\mathrm{~L})$ & $1.54 \pm 0.34(\mathrm{~L})$ & $1 / 4$ \\
\hline Murcott 1 & $8.13 \pm 1.20(\mathrm{M})$ & $3.54 \pm 0.62(\mathrm{M})$ & $0.96 \pm 0.22(\mathrm{~S})$ & $1 / 4$ \\
\hline Murcott 2 & $7.95 \pm 1.18(\mathrm{M})$ & $3.48 \pm 0.55(\mathrm{M})$ & $0.85 \pm 0.21(\mathrm{~S})$ & $1 / 4$ \\
\hline Niva & $8.90 \pm 1.54(\mathrm{M})$ & $4.35 \pm 1.04(\mathrm{~L})$ & $1.54 \pm 0.34(\mathrm{~L})$ & $2 / 4$ \\
\hline Oneco & $7.72 \pm 1.33(\mathrm{M})$ & $3.22 \pm 0.58(\mathrm{M})$ & $1.00 \pm 0.25(\mathrm{~S})$ & $2 / 4$ \\
\hline Ortanique & $7.51 \pm 1.31(\mathrm{M})$ & $3.06 \pm 0.66(\mathrm{M})$ & $1.09 \pm 0.26(\mathrm{M})$ & $1 / 4$ \\
\hline Osceola & $8.29 \pm 1.23(\mathrm{M})$ & $3.78 \pm 0.54(\mathrm{M})$ & $0.98 \pm 0.18(\mathrm{~S})$ & $1 / 3$ \\
\hline Ponkan & $8.37 \pm 1.23(\mathrm{M})$ & $3.96 \pm 0.61(\mathrm{M})$ & $1.33 \pm 0.25(\mathrm{M})$ & $2 / 4$ \\
\hline Ponkan tardia & $8.85 \pm 1.06(\mathrm{M})$ & $3.57 \pm 0.56(\mathrm{M})$ & $1.15 \pm 0.22(\mathrm{M})$ & $1 / 4$ \\
\hline Robinson & $7.23 \pm 1.01(\mathrm{M})$ & $2.44 \pm 0.34(\mathrm{~S})$ & $0.71 \pm 0.12(\mathrm{~S})$ & $2 / 4$ \\
\hline Satsuma & $9.66 \pm 1.32(\mathrm{~L})$ & $3.62 \pm 0.55(\mathrm{M})$ & $1.39 \pm 0.38(\mathrm{M})$ & $2 / 4$ \\
\hline Sunki & $8.15 \pm 1.34(\mathrm{M})$ & $3.26 \pm 0.70(\mathrm{M})$ & $1.01 \pm 0.22(\mathrm{M})$ & $1 / 3$ \\
\hline Tankan & $6.81 \pm 0.99(\mathrm{~S})$ & $3.02 \pm 0.56(\mathrm{M})$ & $1.11 \pm 0.24(\mathrm{M})$ & $1 / 4$ \\
\hline
\end{tabular}

${ }^{(1)}$ Length (cm): 5.0-7.0, S (small); > 7.0-9.0, M (medium); >9.0-11.0, L (large); width (cm): 2.0-3.0, S (small); >3.0-4.0, M (medium); >4.0-5.0, L (large); petiole length $(\mathrm{cm}): 0.5-1.0, \mathrm{~S}$ (small); >1.0-1.5, M (medium); >1.5-2.0, L (large). ${ }^{(2)} 1: 2^{\text {nd }}$ half of August; $2: 1^{\text {st }}$ half of September; $3: 2^{\text {nd }}$ half of September; 4: $2^{\text {nd }}$ half of October. 


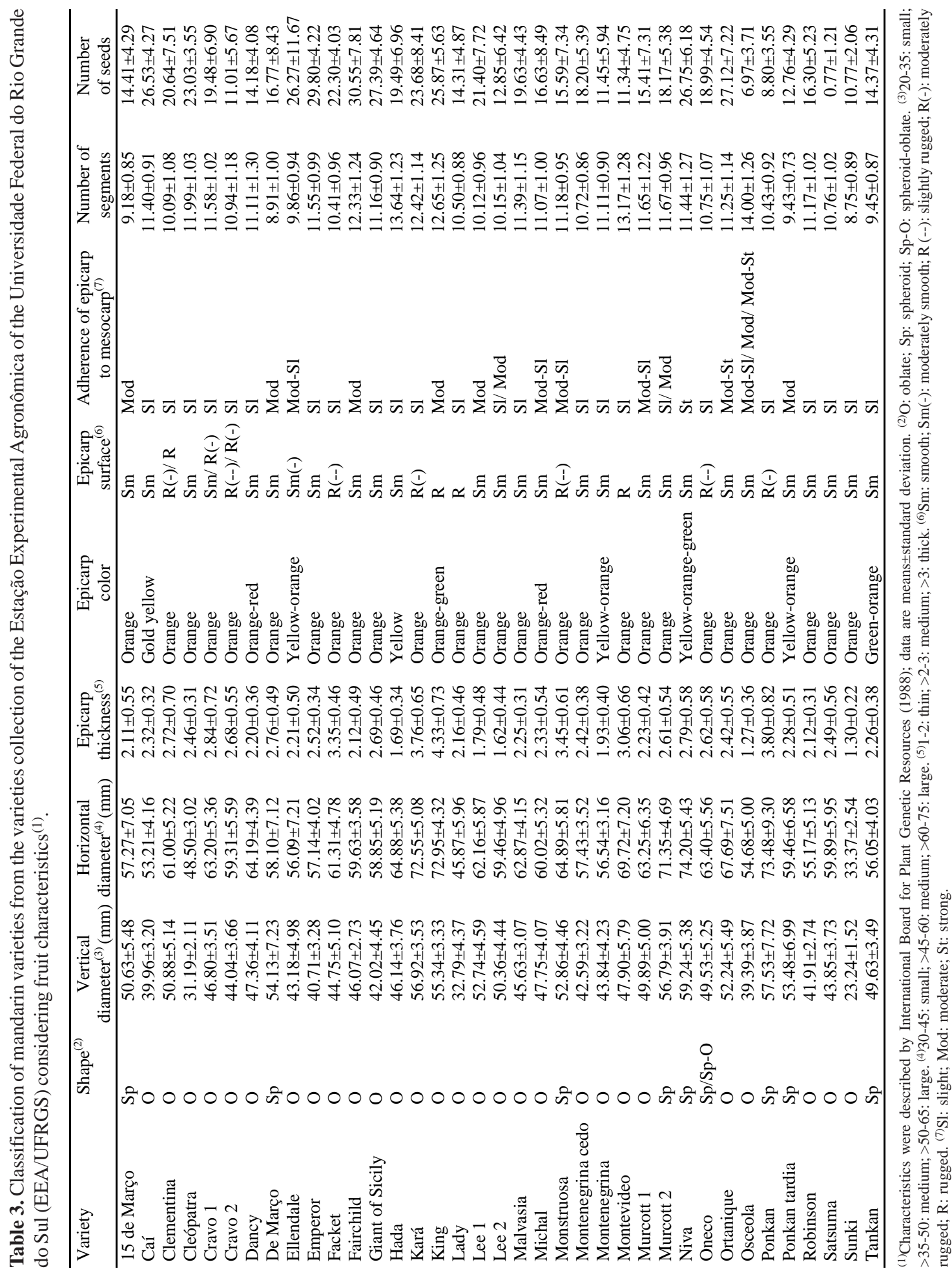


presented slight adherence of epicarp to mesocarp; and epicarp thickness was classified as medium in $68 \%$ of the cultivars. Pulp color, in practically all cultivars $(97 \%)$, was classified as orange. The average number of segments per fruit varied between 10 and 12 in $68 \%$ of the cases, and the average number of seeds per fruit was high in the majority of the cultivars $(92 \%)$.

The dendrogram obtained with the 18 quantitative and qualitative morphologic characteristics, considering the 37 cultivars, shows the formation of three groups, with an average dissimilarity of 0.60 (Figure 1).

The nine primer sets detected a total of 32 amplification fragments, varying from 1 to
6 fragments per primer, and with sizes varying from 100 to 400 base pairs. Only two groups can be distinguished, with three cultivars, 'Kará', 'King' and 'Montevideo', separating from all others (Figure 2). The dissimilarity average was much lower (0.30) than that observed for the morphological traits.

The combination of the two sets of data yielded, as expected, an intermediate pattern (Figure 3). Although the dissimilarity index was still low, five distinct clusters could be discerned, 1, 2, and 4 separating varieties that were grouped in the morphological dendrogram. Varieties of clusters 3 and 5 were grouped together in the morphological cluster 2. With two exceptions ('Satsuma' and 'Monstruosa') the varieties grouped in clusters 1,3 , and 4

Table 4. List of primers used and their respective annealing temperatures.

\begin{tabular}{|c|c|c|}
\hline Primer & Sequence & Annealing temperature \\
\hline CCSM1F & 5' CAGCTCCAAGAAACCCTA 3' & \multirow{2}{*}{$53^{\circ} \mathrm{C}-30 \mathrm{sec}$} \\
\hline $1 \mathrm{R}$ & 5' GCCAATATATCATGCAGGTA 3' & \\
\hline CCSM3F & 5' GCAATGCACCTTGTCATTAG 3' & \multirow{2}{*}{$55^{\circ} \mathrm{C}-30 \mathrm{sec}$} \\
\hline $3 \mathrm{R}$ & 5' CATCACAGGCACTTATGCAG 3' & \\
\hline CCSM4F & 5' ТTCTCCTCATCTTCGACTCC 3' & \multirow{2}{*}{$55^{\circ} \mathrm{C}-90 \mathrm{sec}$} \\
\hline $4 \mathrm{R}$ & 5' CCGATCTTACGACGTATCAA 3' & \\
\hline CCSM6F & 5' ATCTGTGTGAGGACTGAA 3' & \multirow{2}{*}{$51^{\circ} \mathrm{C}-30 \mathrm{sec}$} \\
\hline $6 \mathrm{R}$ & 5' CCTCTATTAATGTGCCTG 3' & \\
\hline CCSM9F & 5' GACTGGATTAGAGTTCTCTG 3' & \multirow{2}{*}{$53^{\circ} \mathrm{C}-30 \mathrm{sec}$} \\
\hline $9 \mathrm{R}$ & 5' ATGGATGTGTTATCTCACTC 3' & \\
\hline CCSM12F & 5' GATTGAATCTTCTGTAGCTC 3' & \multirow{2}{*}{$53^{\circ} \mathrm{C}-30 \mathrm{sec}$} \\
\hline $12 \mathrm{R}$ & 5' ATCATCATCTAGTGTCACTG 3' & \\
\hline CCSM13F & 5' CTAGAGCCGAATTCACC 3' & \multirow{2}{*}{$50^{\circ} \mathrm{C}-30 \mathrm{sec}$} \\
\hline $13 \mathrm{R}$ & 5' AACAGCTACCAAGACACC 3' & \\
\hline CCSM14F & 5' AGTGATGAAGCTAATGAGG 3' & \multirow{2}{*}{$53^{\circ} \mathrm{C}-90 \mathrm{sec}$} \\
\hline $14 \mathrm{R}$ & 5' ССТТСТСТСТTCTTCTCTGT 3' & \\
\hline CCSM19F & 5' GGACACTGTGACGGCTAA 3' & \multirow{2}{*}{$56^{\circ} \mathrm{C}-30 \mathrm{sec}$} \\
\hline $19 \mathrm{R}$ & 5' AGCTACCAAGACACCACC 3' & \\
\hline
\end{tabular}


in the combined analysis are classified identically at two taxonomic levels (subsection Microacrumen, subgroup Megacarpa). 'Cleópatra' and 'Sunki' (which formed cluster 2 in Figure 3 ) are classified in a different subgroup (Microcarpa), while 'Montevideo' and 'Kará' (cluster 5) are classified in a different subsection. The above-indicated exceptions ('Satsuma' and 'Monstruosa') occupy peripheral positions respectively in clusters 1 and 2 of Figure 3.

The fruit characteristics considered indicated that all the varieties studied have potential for commercial use in the State of Rio Grande do Sul, with the exception of those with very small fruits, such as 'Sunki' and 'Cleópatra'. 'Satsuma' was the only variety to present a negligible number of seeds (average of 0.8 per fruit), one of the characteristics mostly required for in natura consumption. The
'Dancy' and 'Michal' varieties should be used as parents in Brazilian breeding programs, since they possess an intense fruit coloration (orange-red), which is required in the consuming market. Another trait to be explored in directed crossings is the slight adherence of the epicarp to mesocarp; this trait is present in many of the varieties.

Federici et al. (1998) studied 73 citrus accessions, 13 of mandarins and 12 of related genera, using RFLP and RAPD markers. They observed the formation of two groups, the first formed by the 'Clementina' variety and other accessions belonging to $C$. reticulata, and the second by accessions belonging to the $C$. reshni, $C$. sunki, $C$. unshiu and C. delicious species. No such distinction is observed in the dendrogram of Figure 3. Nicolosi et al. (2000) studied 13 cultivars of mandarins and other citrus of

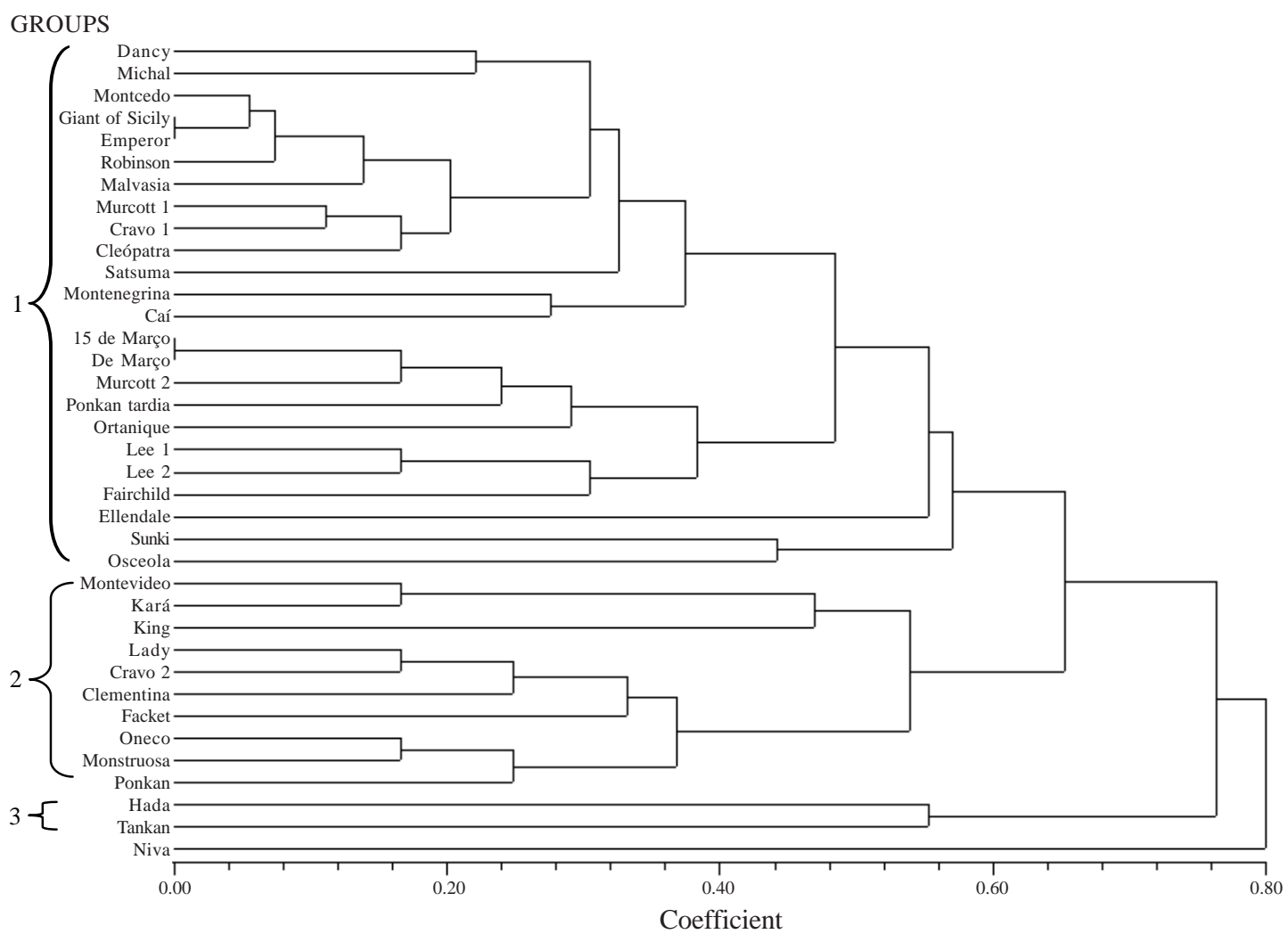

Figure 1. Dendrogram (Manhattan distance) of mandarin cultivars from the varieties collection of the Estação Experimental Agronômica of the Universidade Federal do Rio Grande do Sul (EEA/UFRGS) generated by the qualitative and quantitative morphologic characteristics. 
the Citrus and Papeda subgenera with RAPD and SCAR (Sequence-Characterized Amplified Region) markers. All the mandarin cultivars grouped together; seven of them were also studied here, but did not cluster together in Figure 3. Coletta Filho et al. (1998) analyzed the RAPD diversity among 35 mandarin accessions, including 10 species and 7 hybrids, and verified the formation of two groups. Fourteen of them were also included in the present study, but the clusters distinguished by them were not discernible here.

Based on the above discussed results, Coletta Filho et al. (1998), Federici et al. (1998) and Fang et al. (1998) proposed that mandarins constitute only one species, $C$. reticulata, composed of genetically and morphologically different varieties with a large number of hybrids. They also suggested that the genetic basis of mandarins' domesticated germplasm is quite narrow, what had been previously observed for enzymatic markers (Herrero et al., 1996) and was confirmed by the genetic similarity found for microsatellite markers.

Despite this similarity, the microsatellite results demonstrated that they may be useful in breeding programs to establish early identification of different cultivars, and in distinguishing zygotic from nucellar individuals in seedling populations. On the other hand, the differences between Figures 1 and 2 suggest that morphologic and molecular differences are apparently independent, due to diverse pressures and evolutionary factors.

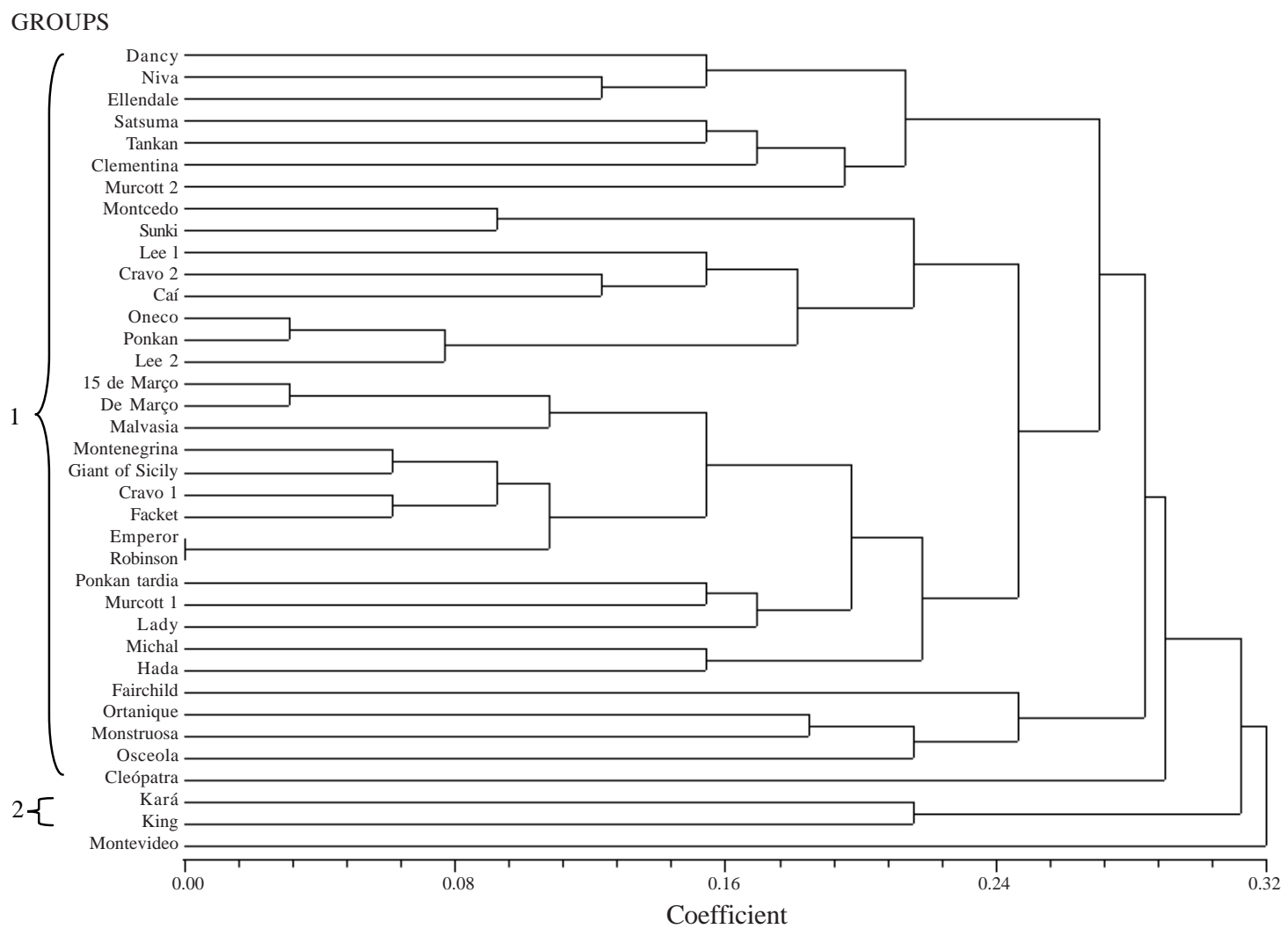

Figure 2. Dendrogram (Manhattan distance) of mandarin cultivars from the varieties collection of the Estação Experimental Agronômica of the Universidade Federal do Rio Grande do Sul (EEA/UFRGS) generated by the microsatellite data. 
GROUPS

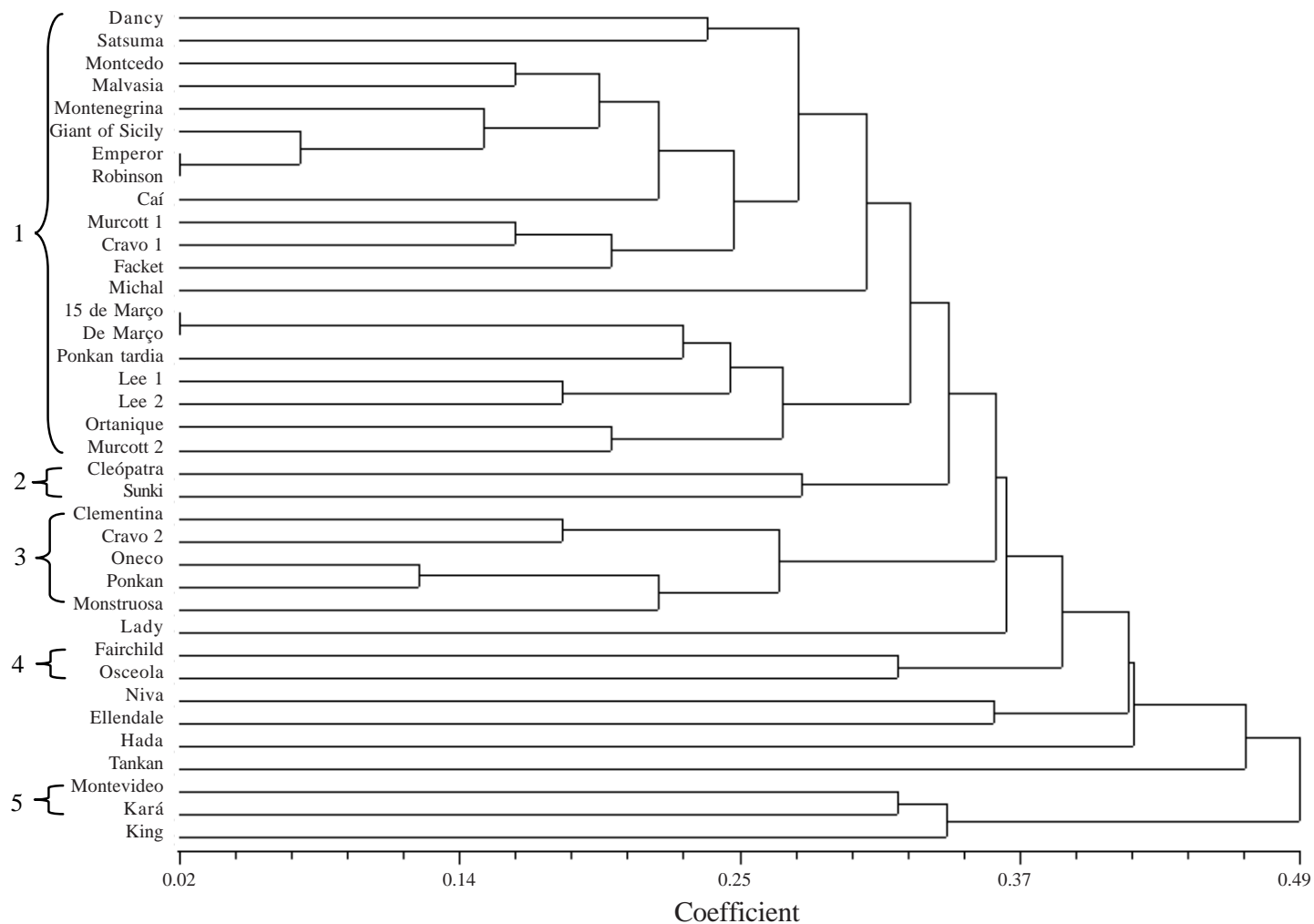

Figure 3. Dendrogram (Manhattan distance) of mandarin cultivars from the varieties collection of the Estação Experimental Agronômica of the Universidade Federal do Rio Grande do Sul (EEA/UFRGS), generated using both the morphologic and microsatellite data.

\section{Conclusions}

1. Despite the fact that the morphologic, agronomic, and microsatellite variability is not extensive, good background material exists for breeding programs.

2. Morphological and molecular patterns of variation do not coincide, therefore complicating attempts of selective improvement.

\section{Acknowledgements}

To Francisco M. Salzano, for suggestions and critical review of the manuscript; to José Fernandes Barbosa Neto, for statistical support; to the Programa de Apoio a Núcleos de Excelência (Pronex),
Financiadora de Estudos e Projetos (Finep), Conselho Nacional de Desenvolvimento Científico e Tecnológico (CNPq), Fundação de Amparo à Pesquisa do Estado do Rio Grande do Sul (Fapergs) and Pró-Reitoria de Pesquisa da Universidade Federal do Rio Grande do Sul (Propesq-UFRGS), for financial support; to the Coordenação de Aperfeiçoamento de Pessoal de Nível Superior (Capes) for the fellowship of Patrícia Koehler-Santos.

\section{References}

BASTIANEL, M. Diversidade genética em citrus e análise de pedigree em uma população segregante de tangerineira 'Lee' [Citrus reticulata $\mathbf{x}(C$. reticulata $\mathbf{x}$ C. paradisi)] obtida por polinização aberta através do marcador molecular RAPD e marcadores 
morfológicos. 1999. 91 f. Dissertação (Mestrado em Fitotecnia) - Universidade Federal do Rio Grande do Sul, Porto Alegre, 1999.

COLETTA FILHO, H. D.; MACHADO, M. A.; TARGON, M. L. P. N.; MOREIRA, M. C. P. Q. D. G.; POMPEU JUNIOR, J. Analysis of the genetic diversity among mandarins (Citrus spp.) using RAPD markers. Euphytica, Dordrecht, v. 102, p. 133-139, 1998.

COLETTA FILHO, H. D.; MACHADO, M. A.; TARGON, M. L. P. N.; POMPEU JUNIOR, J. The use of random amplified polymorphic DNA to evaluate the genetic variability of Ponkan mandarin (Citrus reticulata Blanco) accessions. Genetics and Molecular Biology, Ribeirão Preto, v. 23, n. 1, p. 169-172, 2000.

DOMINGUES, E. T.; SOUZA, V. C.; SAKURAGUI, C. M.; POMPEU JUNIOR, J.; PIO, R. M.; TEÓFILO SOBRINHO, J.; SOUZA, J. P. Caracterização morfológica de tangerinas do banco ativo de germoplasma de citros do Centro de Citricultura Sylvio Moreira/IAC. Scientia Agricola, Piracicaba, v. 56, n. 1, p. 197-206, 1999.

DOYLE, J. J.; DOYLE, L. A rapid DNA isolation procedure for small quantities of fresh leaf tissue. Phytochemical Bulletin, Columbus, v. 19, p. 11-15, 1987.

FANG, D.; KRUEGER, R. R.; ROOSE, M. L. Phylogenetic relationships among selected citrus germplasm accessions revealed by inter-simple sequence repeat (ISSR) markers. Journal of the American Society for Horticultural Science, Alexandria, v. 123, n. 4, p. $612-617,1998$.

FAO (Rome, Italy). Production yearbook. Available at: <http://www.apps1.fao.org/servlet/XteServlet.jrun?>. Access: December 2000.

FEDERICI, C. T.; FANG, D. Q.; SCORA, R. W. Phylogenetic relationships within the genus Citrus (Rutaceae) and related genera as revealed by RFLP and RAPD analysis. Theoretical and Applied Genetics, Berlin, v. 96, p. 812-822, 1998.

HERRERO, R.; ASÍNS, M. J.; CARBONELL, E. A.; NAVARRO, L. Genetic diversity in the orange subfamily Aurantioideae - I. Intraspecies and intragenus genetic variability. Theoretical and Applied Genetics, Berlin, v. 92, p. 599-609, 1996.

INTERNATIONAL BOARD FOR PLANT GENETIC RESOURCES (Rome, Italy). Descriptors for citrus. Rome, 1988. 27 p.

KIJAS, J. M. H.; FOWLER, J. C. S.; THOMAS, M. R. An evaluation of sequence-tagged microsatellite site markers for genetic analysis within Citrus and related species. Genome, Ottawa, v. 38, p. 349-355, 1995.

KIJAS, J. M. H.; THOMAS, M. R.; FOWLER, J. C. S.; ROOSE, M. L. Integration of trinucleotide microsatellites into a linkage map of Citrus. Theoretical and Applied Genetics, Berlin, v. 94, p. 701-706, 1997.

NICOLOSI, E.; DENG, Z. N.; GENTILE, A.; LA MALFA, S.; CONTINELLA, G.; TRIBULATO, E. Citrus phylogeny and genetic origin of important species as investigated by molecular markers. Theoretical and Applied Genetics, Berlin, v. 100, p. 1155-1166, 2000.

ROHLF, F. J. NTSYS - pc numerical taxonomy and multivariate analysis system: version 1.7. New York: State University of New York, 1992. 3 disks.

SARTORI, I. A.; RECKZIEGEL, V. P.; KOLLER, O. C.; BENDER, R. J.; SCHWARZ, S. F. Épocas de maturação de tangerinas na depressão central do Rio Grande do Sul. Pesquisa Agropecuária Gaúcha, Porto Alegre, v. 3, n. 2, p. 171-176, 1997.

SNEATH, P. H. A.; SOKAL, R. R. Numerical taxonomy: the principles and practice of numerical classification. San Francisco: W. H. Freeman, 1973. 546 p.

TANAKA, T. Citrologia: semi centennial commemoration papers on citrus studies. Osaka: Citrologia Supporting Foundation, 1961. $114 \mathrm{p}$.

TANAKA, T. Fundamental discussion of Citrus classification. Studia Citrologica, Osaka, v. 14, p. 1-6, 1977.

THOMAS, M. R.; SCOTT, N. S.; BOTTA, R.; KIJAS, J. M. H. Sequence-tagged site markers in grapevine and citrus. Journal of the Japanese Society for Horticultural Science, Tokyo, v. 67, n. 6, p. 1189-1192, 1998. 